University of Nebraska - Lincoln

DigitalCommons@University of Nebraska - Lincoln

Nebraska Cooperative Fish \& Wildlife Research Nebraska Cooperative Fish \& Wildlife Research Unit -- Staff Publications

2002

\title{
Initial Mortality of Black Bass in B.A.S.S. Fishing Tournaments
}

Gene R. Wilde

Texas Tech University, gene.wilde@ttu.edu

Calub E. Shavlik

Wildlife and Fisheries Management Institute

Kevin L. Pope

University of Nebraska-Lincoln, kpope2@unl.edu

Follow this and additional works at: https://digitalcommons.unl.edu/ncfwrustaff

Part of the Other Environmental Sciences Commons

Wilde, Gene R.; Shavlik, Calub E.; and Pope, Kevin L., "Initial Mortality of Black Bass in B.A.S.S. Fishing Tournaments" (2002). Nebraska Cooperative Fish \& Wildlife Research Unit -- Staff Publications. 88. https://digitalcommons.unl.edu/ncfwrustaff/88

This Article is brought to you for free and open access by the Nebraska Cooperative Fish \& Wildlife Research Unit at DigitalCommons@University of Nebraska - Lincoln. It has been accepted for inclusion in Nebraska Cooperative Fish \& Wildlife Research Unit -- Staff Publications by an authorized administrator of DigitalCommons@University of Nebraska - Lincoln. 


\title{
Initial Mortality of Black Bass in B.A.S.S. Fishing Tournaments
}

\author{
Gene R. Wilde,* Calub E. Shavlik, and Kevin L. Pope \\ Wildlife and Fisheries Management Institute, \\ Mail Stop 2125, Texas Tech University, \\ Lubbock, Texas 79409, USA
}

\begin{abstract}
We studied the initial mortality of black bass Micropterus spp. that were captured, weighed in, and released in fishing tournaments conducted by the Bass Anglers Sportsman Society between 1972 and 1998. Mean annual initial mortality (i.e., mortality before weigh-in and release) ranged from $1 \%$ to $30 \%$. Initial mortality was greatest during the 1970s (15.2\%) and decreased during the 1980s $(5.7 \%)$ and 1990s (1.9\%). Because initial mortality was uniformly low $(\leq 5 \%)$ after 1982 , we used results for 1983-1998 to assess relationships involving initial mortality. Initial mortality was correlated with bag size, mean fish weight per angler, and number of fish per angler. Logistic regression showed that these three variables and their interactions explained significant portions of the variation in black bass initial mortality. Our results suggest that the initial survival of black bass caught in tournaments can be improved by reducing the number or total weight of fish that anglers can hold in their live wells during the day. This could be accomplished by decreasing tournament bag limits.
\end{abstract}

Competitive fishing is a popular use of freshwater fishery resources, and the number and geographic distribution of these events have increased dramatically since the 1970s (Holbrook 1975; Shupp 1979; Duttweiler 1985; Schramm et al. 1991). Most events target black bass Micropterus spp.; however, other species increasingly are targeted (Schramm et al. 1991). Competitive fishing is at times contentious, with anglers and fishery managers expressing concerns about the potential biological and social impacts (Schramm et al. 1991). Among black bass anglers who do not participate in competitive fishing events there are continuing concerns that the mortality of fish captured and brought to weigh-in stations may affect fisheries (Wilde et al. 1998a), and mortality at some tournaments may exceed that viewed as acceptable by most participants (Wilde et al. 2002).

The mortality of black bass captured in competitive fishing events has been recorded since the early 1970s (Holbrook 1975; Wilde 1998). These data show that initial mortality (i.e., mortality before weigh-in and release) of black bass was great-

\footnotetext{
* Corresponding author: gene.wilde@ttu.edu
}

Received June 22, 2000; accepted December 13, 2001 est in the 1970s (19.5\%), decreased in the $1980 \mathrm{~s}$ $(6.6 \%)$, and showed no further decrease during the 1990s (6.5\%) (Wilde 1998). Much of the decrease in initial mortality between the 1970s and 1980s has been attributed to adoption of catch-andrelease fishing by tournament participants (Barnhart 1989) and refinement of fish handling techniques by tournament participants and organizers (Schramm et al. 1985). However, a more complete understanding of temporal variation in mortality and how it has been affected by changes in tournament practices and angler behavior is complicated by the diversity of procedures, regulations, and rules under which different tournaments are conducted. For example, mortality of tournamentcaught black bass is related to tournament size (Schramm et al. 1985; Hartley and Moring 1995; Ostrand et al. 1999) and the rules and procedures by which tournaments are conducted (Kwak and Henry 1995; Weathers and Newman 1997; Ostrand et al. 1999).

The Bass Anglers Sportsman Society (B.A.S.S.) has conducted fishing tournaments for black bass since the 1960s. Since 1972, B.A.S.S. has kept records of the number of fish captured and the number released alive at each of its tournaments, allowing calculation of initial mortality of black bass at these events. Because B.A.S.S. tournaments are conducted with standardized procedures and rules, they provide consistent data for the examination of temporal trends in initial mortality and the relationships between such mortality and potential explanatory variables.

In this paper we describe temporal changes in the initial mortality of black bass captured in tournaments conducted by B.A.S.S during the 27 years from 1972 to 1998 . Also, we use a subset of these data, collected from 1983 to 1998 , to assess the relationships between initial mortality and (1) bag size, (2) mean weight of fish per angler, and (3) mean number of fish per angler.

\section{Methods}

Individual tournament records maintained by B.A.S.S. since 1972 include the number of anglers, tournament duration (number of days), bag size 
(maximum number of fish an angler may bring to weigh-in), and number and weight of black bass weighed in. These tournaments typically last 3-4 $\mathrm{d}$ (range $=3-6 \mathrm{~d}$ ), and contestants compete for prizes based on the total weight of fish brought to weigh-in over the course of the tournament. Length of the tournament day ranged from 7 to 10 $\mathrm{h}$, ending with a mid- to late-afternoon weigh-in at which the numbers of live and dead fish (as determined by tournament officials) and total weight captured per angler were recorded. We used tournament records provided by B.A.S.S. (Bass Anglers Sportsman Society, Montgomery, Alabama) to assess factors affecting initial mortality in 284 of the B.A.S.S. tournaments.

We calculated initial mortality for each tournament as the proportion of dead fish brought to weigh-in divided by the total number of fish brought to weigh-in. The B.A.S.S. records did not facilitate calculating the mortality of fish captured and released before weigh-in (including culled fish). Fish were determined to be dead at weighin if they failed to show any sign of life (D. Kendrick, B.A.S.S., personal communication). We also calculated mean initial mortality for all tournaments $(N=6-18)$ held during each year and for each of three periods: 1972-1979, 1980-1989, and 1990-1998. We combined results for concurrently conducted "professional" and "amateur" tournaments because there was no evidence of any systematic difference in initial mortality (one-way analysis of variance: $F=0.02 ; \mathrm{df}=1,98 ; P=$ $0.8933)$. Initial mortality was high and variable in early tournaments but decreased to about $5 \%$ after 1982. Therefore, in assessing the relationship between initial mortality and various explanatory variables, we treated the data collected at the 1983-1998 tournaments as a homogeneous data set that was minimally affected by tournament procedures.

We used Spearman's rank correlation coefficient $\left(r_{s}\right)$ to assess the relationship between black bass initial mortality and bag size, mean weight of fish per angler per day, and mean number of fish per angler per day. We used logistic regression to model the effects of bag size and mean weight and number of fish per angler on black bass initial mortality. We fit a model that included main effects and all interaction terms, retaining all significant $(\alpha=0.05)$ terms. The general model fit was

$$
P(m)=e^{\eta} /\left(1+e^{\eta}\right),
$$

where $P(m)$ is the probability of mortality, $e$ is the

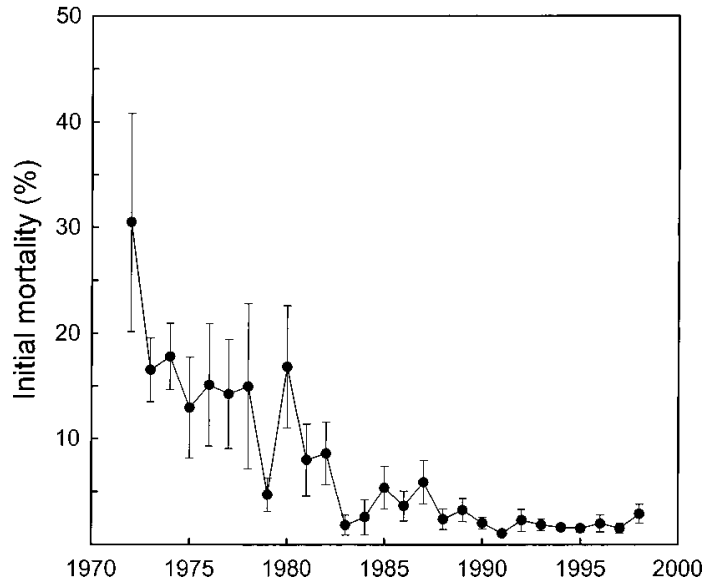

FIGURE 1.-Means and standard errors of annual initial mortality for black bass captured in Bass Anglers Sportsman Society fishing tournaments from 1972 to 1998.

base of natural logarithms, and $\eta$ is a linear combination of the independent variables (i.e., $\eta=\beta_{0}$ $+\beta_{1} X_{1 i}+\beta_{2} X_{2 i}+\beta_{3} X_{3 i}$, with $\beta_{0}$ being a regression intercept, $\beta_{1}, \beta_{2}, \beta_{3}$ being regression coefficients, and $X_{1 i}, X_{2 i}, X_{3 i}$ representing bag size, mean fish weight per angler, and number of fish per angler for the $i$ th tournament). All statistical analyses were performed using SAS (SAS Institute 1999) and S-Plus 2000 (MathSoft, Inc. 1999).

\section{Results and Discussion}

Measurements of initial mortality were available for 284 B.A.S.S. tournaments held from 1972 through 1998. Mean initial mortality ranged from $1 \%$ in 1991 to $30.5 \%$ in 1972 (Figure 1). Initial mortality decreased from $30 \%$ in 1972 to $16.5 \%$ in 1973. Holbrook (1975) attributed this decrease to a reduction in the number of tournaments held during warm weather and modifications of weighin equipment and procedures used by B.A.S.S. However, B.A.S.S. also began requiring aeration of live wells and assessing penalties for dead fish during this period (Kendrick, personal communication), both of these requirements probably contributed to the observed decrease in initial mortality.

Initial B.A.S.S. tournament mortality was $15.2 \%$ in the $1970 \mathrm{~s}, 5.7 \%$ in the $1980 \mathrm{~s}$, and $1.9 \%$ in the 1990s. These measurements are comparable to those reported by Wilde (1998) for all black bass tournaments held during these same 10-year periods, namely, $19.5,6.6$, and $6.5 \%$, respectively. Close agreement among measurements for the 
1970s and 1980s is expected because several B.A.S.S. tournaments are included in both data sets. Also, dead-fish penalties and other procedures used to promote survival in B.A.S.S. national tournaments subsequently were adopted by local B.A.S.S. affiliates and other tournament organizers (e.g., Schramm et al. 1985).

Although Wilde (1998) found no difference in initial mortality measurements among tournaments conducted in the 1980s and 1990s, initial mortality in B.A.S.S. tournaments declined by a factor of three during this period. Initial mortality estimates in B.A.S.S. tournaments held since 1990 (1.9\%) are comparable to those available for large tournaments ( $\geq 50$ anglers or prizes in excess of US\$200) in California (1.9\%; Lee et al. 1993), Florida (2.4\%; Watson and Johnson 1997), and Texas (1.8\%; Ostrand et al. 1999). Ostrand et al. (1999) suggested that tournament size is an indirect measure of organization and that larger tournaments have and enforce rules and procedures that promote fish survival.

Initial mortality in B.A.S.S. tournaments held from 1983 to 1998 was correlated with bag size ( $\left.r_{s}=0.20, N=201, P=0.0044\right)$ and mean weight $\left(r_{s}=0.24, N=201, P=0.0005\right)$ and number $\left(r_{s}\right.$ $=0.34, N=201, P<0.0001)$ of fish per angler. All correlations were positive, indicating that initial mortality increases with the number and weight of fish that anglers can capture, hold in live wells, and bring to weigh-in (Figure 2). We are aware of no previous examination of the relationship between tournament bag size and initial mortality. In previous studies (Schramm et al. 1985, 1987; Weathers and Newman 1997), correlations $\left(r, r_{s}\right)$ between initial mortality and mean weight of fish per angler ranged between -0.13 and 0.38 . Using meta-analysis, Wilde (1998) estimated that the mean weighted correlation between initial mortality and weight of fish captured was 0.31 ( $\mathrm{SE}=$ $\pm 0.197)$, which is only slightly greater than the correlation we observed $\left(r_{s}=0.24\right)$. Schramm et al. $(1985,1987)$ and Weathers and Newman (1997) reported correlations between initial mortality and number of fish per angler to be statistically nonsignificant and variable, ranging from -0.20 to 0.43 . Using the methods of Hunter and Schmidt (1990) and Wilde (1998), we calculated a mean weighted correlation of $0.06 \pm 0.160$ for these studies, which is much lower than the correlation we observed $\left(r_{s}=0.34\right)$.

Logistic regression for tournaments held during 1983-1998 showed that initial mortality was affected by bag size and the mean weight and number
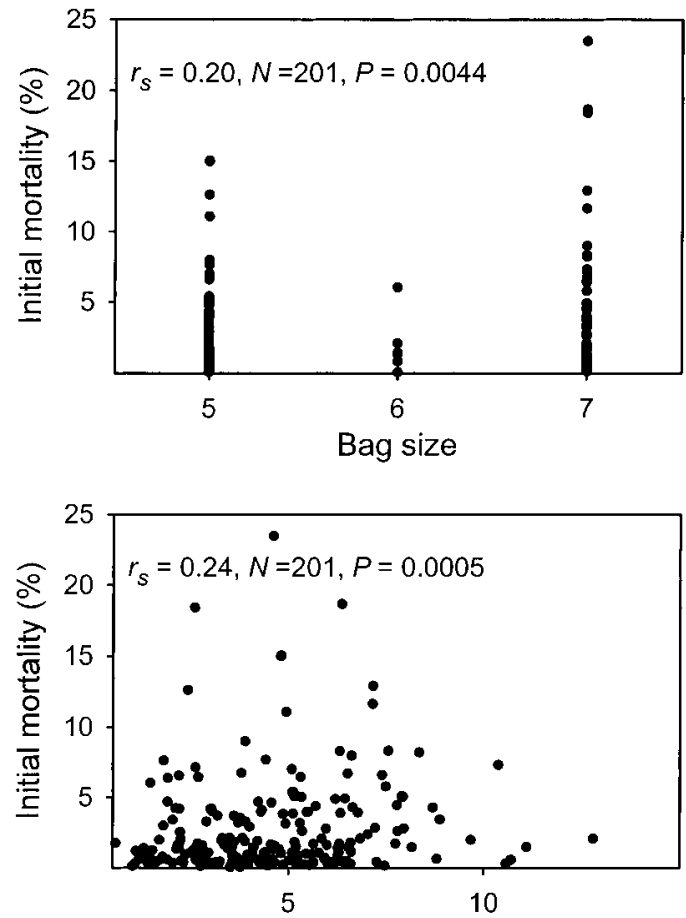

Mean weight (Ibs) of fish per angler per day

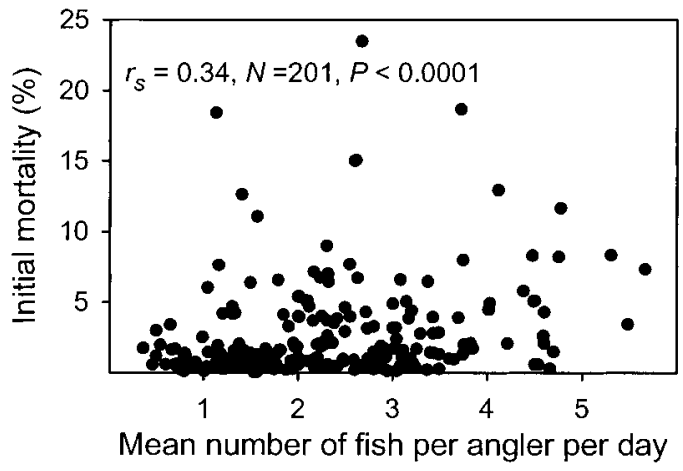

FIGURE 2.-Relationships between initial mortality and bag size, mean weight of fish captured per angler per day, and mean number of fish captured per angler per day in Bass Anglers Sportsman Society fishing tournaments from 1983 to 1998 . The symbol $r_{s}$ represents Spearman's rank correlation coefficient.

of fish per angler, as well as by all two- and threeway interactions between these variables (Table 1). These results are consistent with the correlation analyses presented above; however, logistic regression shows that bag size is the single most influential variable (of those we examined) affecting initial mortality. Therefore, our correlations between initial mortality and mean weight 
TABLE 1.-Analysis of deviance for the logistic regression of black bass initial mortality on bag size, average weight of fish per angler, and average number of fish per angler in Bass Anglers Sportsman Society fishing tournaments held during 1983-1998. Also shown are regression coefficients and their standard errors.

\begin{tabular}{lrrrrr}
\hline \multicolumn{1}{c}{ Factor } & \multicolumn{1}{c}{$\chi^{2}$} & df & $P$ & Coefficient & SE \\
\hline Intercept & & & & 7.37 & 0.538 \\
Bag & $1,972.79$ & 1 & 0.0001 & -0.35 & 0.085 \\
Weight & 559.03 & 1 & 0.0001 & -0.13 & 0.143 \\
Number & 206.26 & 1 & 0.0001 & -1.93 & 0.232 \\
Bag $\times$ weight & 79.30 & 1 & 0.0001 & -0.02 & 0.023 \\
Bag $\times$ number & 15.00 & 1 & 0.0001 & 0.22 & 0.036 \\
Weight $\times$ number & 236.98 & 1 & 0.0001 & 0.29 & 0.040 \\
Bag $\times$ weight $\times$ number & 31.70 & 1 & 0.0001 & -0.03 & 0.006 \\
\hline
\end{tabular}

and number of fish per angler may be inflated because of their cross-correlation with bag size.

Water temperature, a major determinant of tournament-associated mortality in black bass (Wilde 1998), was not recorded at B.A.S.S. tournaments. Although we believe that differences in water temperature among tournaments would be an important predictor of initial mortality, temperature effects might not be as pronounced as those described by Wilde (1998). The B.A.S.S. tournaments follow a south-to-north circuit to minimize tournament activity during periods when water temperatures, and hence mortality, are high. Tournaments are conducted in winter and spring in southern states and are then moved progressively northward during summer. This coincidentally minimizes among-tournament variation in water temperature, thus limiting the potential importance of water temperature as a predictor of mortality in B.A.S.S. tournaments.

\section{Management Implications}

Despite the small range in bag size (5-7 fish) in B.A.S.S. tournaments since 1982 , based on our logistic regression results, bag size was the best predictor of initial mortality among the variables studied. Fishery managers and tournament organizers often have some discretion in setting bag limits for competitive fishing events and may consider reducing limits when tournament mortality may be high-for example, during periods characterized by high water temperatures (Wilde 1998). Many tournaments already are conducted with voluntarily reduced bag limits (e.g., Wilde et al. 1998b). This is most commonly observed in team tournaments in which the bag limit for each two-person team is voluntarily reduced by $50 \%$ to equal the one-person lake or statewide limit. As fishery managers gain a better understanding of anglers' motives for participating in fishing tournaments, they will be able to identify and target those groups that are likely to be most supportive of reduced bag limits as a means of reducing tournament-associated mortality (Wilde et al. 1998a).

\section{Acknowledgments}

We thank B.A.S.S. for making these data available. We also thank D. Kendrick and S. King for helpful discussions and G. E. Gilliland and B. D. Shupp for commenting on the manuscript. This is contribution T-9-917 of the College of Agricultural Sciences and Natural Resources, Texas Tech University, Lubbock.

\section{References}

Barnhart, R. A. 1989. Symposium review: catch-andrelease fishing, a decade of experience. North American Journal of Fisheries Management 9:74-80.

Duttweiler, M. W. 1985. Status of competitive fishing in the United States: trends and state fisheries policies. Fisheries 10(5):5-7.

Hartley, R. A., and J. R. Moring. 1995. Differences in mortality between largemouth and smallmouth bass caught in tournaments. North American Journal of Fisheries Management 15:666-670.

Holbrook, J. A., II. 1975. Bass fishing tournaments. Pages 408-414 in H. Clepper, editor. Black bass biology and management. Sport Fishing Institute, Washington, D.C.

Hunter, J. E., and F. L. Schmidt. 1990. Methods of metaanalysis. Sage Publications, Newbury Park, California.

Kwak, T. J., and M. G. Henry. 1995. Largemouth bass mortality and related causal factors during live-release fishing tournaments on a large Minnesota lake. North American Journal of Fisheries Management 15:621-630.

Lee, D. P., I. Paulsen, and W. Beer. 1993. Trends in black bass fishing tournaments in California, 19851989. California Fish and Game 79:1-12.

MathSoft, Inc. 1999. S-Plus 2000 users guide. MathSoft, Inc., Seattle.

Ostrand, K. G., G. R. Wilde, D. W. Strickland, and M. I. Muoneke. 1999. Initial mortality in Texas black bass fishing tournaments. North American Journal of Fisheries Management 19:1124-1128. 
SAS Institute. 1999. SAS proprietary software, version 8. SAS Institute, Cary, North Carolina.

Schramm, H. L., Jr., P. J. Haydt, and N. A. Bruno. 1985. Survival of tournament-caught largemouth bass in two Florida lakes. North American Journal of Fisheries Management 5:606-611.

Schramm, H. L., Jr., P. J. Haydt, and K. M. Porter. 1987. Evaluation of prerelease, postrelease, and total mortality of largemouth bass caught during tournaments in two Florida lakes. North American Journal of Fisheries Management 7:394-402.

Schramm, H. L., Jr., M. L. Armstrong, N. A. Funicelli, D. M. Green, D. P. Lee, R. E. Manns, Jr., B. D. Taubert, and S. J. Waters. 1991. The status of competitive sport fishing in North America. Fisheries 16(3):4-12.

Shupp, B. D. 1979. 1978 status of bass fishing tournaments in the United States. Fisheries 4(6):11-19.

Watson, R. J., and E. R. Johnson. 1997. 1992-1995 bass tournament permitting and research. Florida Game and Freshwater Fish Commission, Completion Report, Tallahassee.
Weathers, K. C., and M. J. Newman. 1997. Effects of organizational procedures on mortality of largemouth bass during summer tournaments. North American Journal of Fisheries Management 17: 131-135.

Wilde, G. R. 1998. Tournament-associated mortality in black bass. Fisheries 23(10):12-22.

Wilde, G. R., D. H. Larson, W. H. Redell, and G. R. Wilde III. 2002. Mortality of black bass in three Texas fishing tournaments. Texas Journal of Science 54:125-132.

Wilde, G. R., R. K. Riechers, and R. B. Ditton. 1998a. Differences in attitudes, fishing motives, and demographic characteristics between tournament and nontournament black bass anglers in Texas. North American Journal of Fisheries Management 18: 422-431.

Wilde, G. R., D. W. Strickland, K. G. Ostrand, and M. I. Muoneke. 1998b. Characteristics of Texas black bass fishing tournaments. North American Journal of Fisheries Management 18:972-977. 